This item was submitted to Loughborough's Research Repository by the author.

Items in Figshare are protected by copyright, with all rights reserved, unless otherwise indicated.

\title{
Learning communities in mathematics: creating an inquiry community between teachers and didacticians
}

PLEASE CITE THE PUBLISHED VERSION

http://www.tandfonline.com/doi/abs/10.1080/14794800008520148

\section{PUBLISHER}

(c) Routledge

VERSION

AM (Accepted Manuscript)

LICENCE

CC BY-NC-ND 4.0

\section{REPOSITORY RECORD}

Jaworski, Barbara. 2019. "Learning Communities in Mathematics: Creating an Inquiry Community Between Teachers and Didacticians". figshare. https://hdl.handle.net/2134/8807. 
This item was submitted to Loughborough's Institutional Repository (https://dspace.lboro.ac.uk/) by the author and is made available under the following Creative Commons Licence conditions.

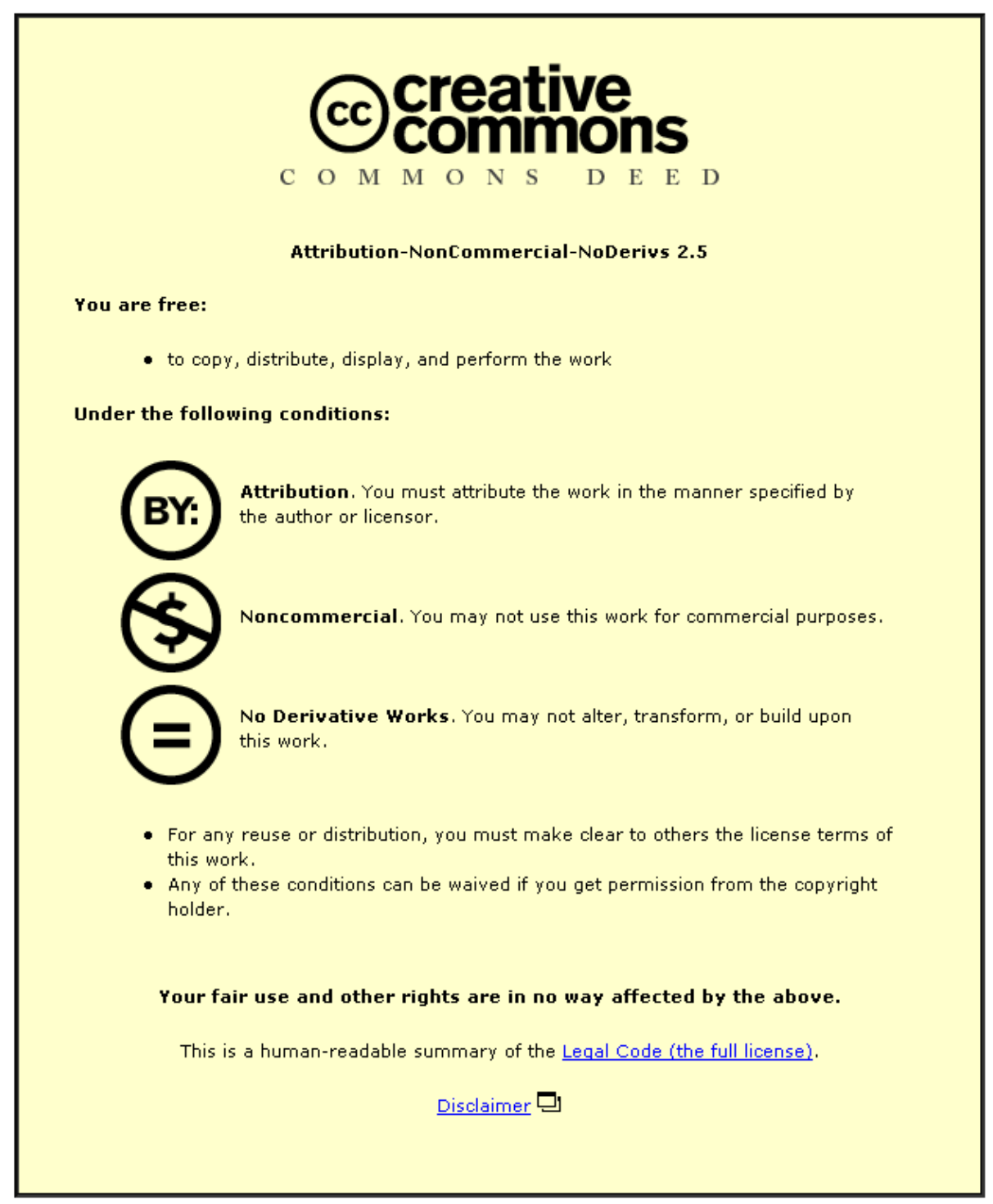

For the full text of this licence, please go to: http://creativecommons.org/licenses/by-nc-nd/2.5/ 


\title{
LEARNING COMMUNITIES IN MATHEMATICS: Creating an inquiry community between teachers and didacticians
}

\author{
Barbara Jaworski
}

\section{Agder University College, Norway}

This paper reports on a project designed to develop inquiry communities between teachers and didacticians, aimed at improving the learning of mathematics in classrooms, and at studying the processes, practices, issues and outcomes in and of the project. Theoretical notions of inquiry and community underpin the project. The focus here is largely methodological, tracing the origination and development of the project and decisions taken through its first phases. The project is seen to be situated within a 'developmental' research paradigm in which research both studies the developmental process and contributes centrally to it. Issues in the interpretation of inquiry practices in mathematics learning and teaching and the building of communities at various levels are seen as important outcomes. The roles and relationships of teachers and didacticians emerge as key concepts in the developmental process.

\section{Background to the Learning Communities in Mathematics project}

Research nationally and internationally shows that mathematical learning in classrooms in Norway is problematic: students' achievement does not meet expectations and curriculum goals are not satisfactorily achieved (Brekke et al, 1995; Alseth et al 2003). The Learning Communities in Mathematics (LCM) project ${ }^{1}$ focuses on teaching and on ways in which teaching might be adapted to achieve better learning for students at all levels. Questions relating to what is meant by "better learning" are addressed as part of the project.

The LCM project was conceived in Norway as a research-and-development project in which teachers of mathematics at all levels of schooling work with didacticians ${ }^{2}$ from a university college to explore approaches to teaching and their outcomes for students. It aims to design and study mathematics teaching development for the improved learning of mathematics. The developmental process and issues this process raises for both teachers and didacticians are central to what is studied in the project. All participants in the project are seen as learners, inquiring into learning and teaching processes at various levels, and working together in designated communities. The project proposal was written by the team of didacticians of mathematics at Agder University College responding to an invitation for bids from the Norwegian Research Council (NFR). Deadlines for the bid did not allow time for prior consultation with prospective school partners, so collaboration with schools has followed its acceptance. 
This paper discusses some of the decisions taken in operationalizing the project according to its theoretical aims and discusses tensions and issues that arose during this

process. At the time of writing, the project has reached the end of Phase 1, which might be seen in retrospect as a phase of "community building". We have now started Phase 2, seen in prospect as a phase of "realizing partnership".

\section{Theoretical perspectives: inquiry and community}

Conceptualization in the LCM project drew both on the interests and expertise of the didacticians and on the research literature. Theoretical notions of inquiry and community are central to this conceptualisation. Briefly, inquiry was seen to promote better learning opportunities: i.e., opportunities to develop better - conceptually rooted learning; community was seen to provide sociosystemic frameworks to nurture and support inquiry building.

\section{Inquiry}

Chambers' dictionary suggests that to inquire means to ask a question, to make an investigation, to acquire information, or to search for knowledge. This fits with Wells (1999) perspective of dialogic inquiry as "a willingness to wonder, to ask questions, and to seek to understand by collaborating with others in the attempt to make answers to them" (p. 122).

In the project proposal, the didaticians saw learners at all levels as developing understandings through inquiry, resulting in developments in cognitive structures and cognitive processing both for individuals and for communities. Inquiry is seen as a tool through which intersubjectivity can be seen to develop. As individuals make sense of concepts and relationships, whether in mathematics, in teaching mathematics or in engaging in a research process, knowledge and understanding grow both for individuals and for the communities of which they are a part. Reflection on the processes of inquiry develops metacognitive activity in which learners becomes more knowledgeable about their own learning (Cobb, 1996; Glasersfeld, 1995; Jaworski, 1994; Mason, 2001; Wells, 1999).

\section{Inquiry communities}

The project proposal draws on a view of learning as a fundamentally social process in which learning between people leads to learning of the individuals who are involved (Vygotsky, 1978). It also recognizes the situated and distributed nature of knowledge in communities of practice (Lave \& Wenger, 1991; Wenger 1998). Interaction and communication in learning communities are therefore seen as fostering common understandings and supporting individual growth. Teaching can be regarded as a practice which has experienced members (old stagers) and supports newcomers (peripheral participants) who will be drawn into the practices of teaching and contribute 
to the development of those practices. The theory of 'communities of practice' can, however, describe and explain perpetuation of practices in which achievement is not as high as is desired. Therefore we believe in nurturing inquiry communities (Wells, 1999) in which existing practices are questioned and alternative practices explored. In discussing the theoretical position of "community of inquiry", I have drawn on Wenger's (1998) three modes of belonging to a community of practice: engagement, imagination and alignment (Jaworski, in press). I suggest that formation of a community of inquiry requires "critical" alignment within a community of practice. According to Wells (1999), inquiry communities are a special form of communities of practice. They are distinguished by forms of 'metaknowing' that develop from inquiry in reflective and reflexive processes. In LCM, we think of inquiry communities as being more than communities of practice. In a community of inquiry, inquiry is not the practice of a community of practice: rather, we see inquiry both as a tool for developing practice, and as a way of being in practice (Jaworski, 2004a).

The LCM project envisages inquiry as operating at three levels:

1. Inquiry in mathematics:

a. Teachers and didacticians exploring mathematics together in tasks and problems in workshops;

b. Pupils in schools learning mathematics through exploration in tasks and problems in classrooms.

2. Inquiry in teaching mathematics:

Teachers using inquiry in the design and implementation of tasks, problems and mathematical activity in classrooms in association with didacticians.

3. Inquiry in developing the teaching of mathematics:

Teachers and didacticians researching the processes of using inquiry in mathematics and in the teaching and learning of mathematics.

The project aims to promote inquiry as a way of being by using inquiry as a tool at all the three levels mentioned above. This includes the design and use of inquiry tasks to engage students in exploring and questioning in mathematics; design and exploration by teachers of new materials and approaches to teaching mathematics; and design and critical examination of research practices to reveal key characteristics and issues from the practices studied. An aim is that using inquiry as a tool will promote an inquiry stance (inquiry as a way of being) to teaching and research.

\section{Design research and developmental research}

The LCM project can be seen to relate to the design research paradigm, which has been described as: 
An emerging research dialect ...contrasting with dialects of confirmation or description ... attempts to support arguments constructed around the results of active innovation and intervention in classrooms. The operative grammar, which draws upon models from design and engineering, is generative and transformative. It is directed primarily at understanding learning and teaching processes when the researcher is active as an educator. (Kelly, 2003)

Since design research is just one mode of research activity supporting "active innovation and intervention in classrooms" (Jaworski, 2004b), we prefer to think of a developmental paradigm in which the operative grammar is "generative and transformative”, and to see 'design' as one factor in development. Thus, we see "arguments constructed around the results of active innovation and intervention in classrooms" as being fundamentally developmental since they are rooted in emergent thinking in inquiry communities, and themselves promote development of thinking and practice (Cestari et. al., 2005).

For the LCM Project, Kelly's term educator includes both teachers and didacticians. In operationalizing a developmental approach , we (didacticians) looked for forms of activity in which we might develop and use inquiry approaches together with our fellow participants (didacticians and teachers). Broadly, we conceptualized four kinds of activity:

- Creating Partnerships: Didacticians and teachers work together for mutual benefit and support - both should be involved in design and implementation at conceptual levels for the success of innovation.

- Designing Materials and Approaches: Design of tasks for workshops and classrooms; design of approaches to learning and teaching; design of research/inquiry to learn about developmental processes and learning outcomes.

- Reflective Action in the use of designed materials and approaches and (critically) reflective questioning of outcomes.

- Research into all of the above in relation to research questions about the realization of inquiry communities and their contribution to improved learning.

The role of teachers in this work needs some clarification. Wittmann suggests that "teachers need to be trained and regarded as partners in research and development and not as mere recipients of results” (1998, p. 95). Moreover, he says that design "cannot be left to teachers...The teacher can be compared more to a conductor than to a composer, or perhaps better to a director ... than to a writer of a play" (p.96). While we agree that teachers should be partners, the nature of such partnership is a focus of study within the project. In developmental research, teachers and didacticians are seen as co-learners:

In a co-learning agreement, researchers and practitioners are both participants in processes of education and systems of schooling. Both are engaged in action and 
reflection. By working together, each might learn something about the world of the other. Of equal importance, however, each may learn something more about his or her own world and its connections to institutions and schooling. (Wagner, 1997, p 16)

Together, therefore, teachers and didacticians study the processes and practices of engaging in inquiry of various sorts, in various ways.

The involvement of teachers in research is seen both positively and problematically in the methodological literature. McIntyre, for example, points out that teachers are not trained to be researchers, and that teaching is a demanding job:

... it seems unreasonable to demand of teachers that they be researchers as well as teachers, when the expertise required for the two activities is so different (1997, p. 33).

Nevertheless, McIntyre acknowledges, with particular reference to the work of John Elliott (e.g., Elliott 1991), that there are those who see teachers' involvement in research as the only way in which teaching will develop. Our project position is towards the latter; however, I discuss below some of the issues this has raised for the LCM project.

Thus, the project studies the processes involved in creating communication and collaboration between teachers and didacticians in which theoretical ideas and visions can be interpreted in practice, produce insights into key issues in developing inquiry communities to enhance mathematics teaching and learning, and provide indications for sustainable practices in mathematics teaching development and learning improvement.

The use of "we" here begs the question of who is in focus at different times. Teachers and didacticians bring different knowledge and skills. In the early stages of the project, workshops were planned and coordinated by didacticians with the aim of drawing teachers into professional dialogue and developing a common discourse. Developing community requires us all to trust and have confidence in working together, respecting particular knowledge and expertise. Teachers have fundamental knowledge of pupils and of activity in schools, school ethos and systemic organization. Didacticians bring theoretical knowledge, for example in promoting inquiry. It was our aim that all participants should develop awarenesses of what inquiry can mean and what practices might be involved in the school environment. Teachers have specific needs in developing inquiry approaches and these needs should be revealed and addressed. Didacticians need to learn about issues that have to be addressed in promoting inquiry in schools. The reality is interestingly both similar to and different from the aims and planning as I report in the next sections.

\section{Project design and operationalization}

The project was designed initially by didacticians with the express wish that teachers should be partners in design within the project. To some extent these are contradictory 
aims, but not entirely. Without the original conceptualization by didacticians there would be no project: as stated already, there was no time for proper consultation with schools and teachers before submitting our bid. If such a consultation had been possible, a conceptualization phase would have been necessary in which the perceptions and perspectives of all concerned could have developed into common purpose. To an extent, Phase 1 of the project emerged as such a conceptualization phase. This will be explained below. In this section, I explain elements of the project design (what was proposed) and comment on their interpretation to date in the project.

\section{Main elements of design}

Given didacticians' focus on inquiry and community, the project proposal suggested that inquiry would be operationalized in Phase I of the project in design and innovation in three modes of activity to be researched. Firstly, all participants should have the chance to engage in activities involving inquiry, to discuss the nature and outcomes of such activities, and together to suggest how inquiry might become central to teaching. Workshops would be designed to contribute to these aims. Secondly, inquiry in schools would develop through teams in each school working to design classroom activity. Thirdly, ideas and materials designed by the school teams would be used in classrooms and their use studied closely, with feedback to future design and increased knowledge of the design process. Thus we envisaged:

1. Workshops at the college: Teachers and didacticians working together on mathematical problems and tasks and asking questions about using inquiry in classrooms. Creating a community of inquirers, all learning at a variety of levels.

2. Teacher teams working in schools: Teachers building on experiences in (1), working together within a school to design mathematical tasks for the classroom. Asking questions about pupils’ learning of mathematics. Drawing on support from didacticians according to needs.

3. Innovative teaching in classrooms: Teachers teaching classes using designed tasks drawing on experiences from (1) and design at (2) to engage students in inquiry and learning in mathematics. Didacticians observing and studying classroom activity.

Modes (1) and (2) were designed to take place simultaneously, with workshops developing starting points for thinking and activity in teacher teams in schools, largely in the autumn. Data would be collected from workshops and as many school events as possible. Mode (3) follows cycles of modes (1) and (2) with teachers and didacticians playing complementary roles in teaching and research. Learning from mode (3) could feed back to further cycles of modes (1) and (2). Data would be collected from a selection of lessons and from conversations with teachers and pupils, largely in the 
spring. An intense period of analysis would follow data collection and lead into Phase 2 of the project. The nature of Phase 2 was left open to respond to our learning in Phase 1.

Following the acceptance of our proposal, the first six months of the project was devoted to didacticians' detailed planning of activity in which schools and teachers were recruited and workshops planned. In retrospect, this work might be seen as 'Phase 0', since we now recognize its importance in the development of inquiry and community, firstly within the team of didacticians, and subsequently in the growth of a project community, as I discuss further below.

\section{Contracts between schools and college.}

During our introductory phase, we sent letters to schools in the vicinity of the college inviting them to participate in the project. We hoped to work with 6 schools. Following the invitations, we held a meeting at the college attended by about 25 teachers and principals representing 8 schools spanning pupils' ages from 6 to 19. We suggested that developmental activity in the project could support a school's own developmental goals and contribute to the professional development of teachers in the school. We asked for a commitment to the project by the school principal and a minimum of three teachers within a school. Principals should agree to support teachers, contribute to time and other resources and disseminate findings in and beyond the school. Teachers should be participants in the project, attending workshops and engaging in task design and classroom innovation. Didacticians should design workshops at the college, and work with teachers in schools according to schools' own developmental goals. Funding designated for school activity should be shared equally between the schools, with schools having autonomy as to its use. Inquiry and community should be fundamental to all activity. Schools should allow data collection in classrooms (including videorecording) and help to obtain the necessary permissions from students and their parents.

7 schools, reflecting a range of age groups and social settings volunteered to participate. A second meeting was held to address particular questions and start a process of relationship building. One school suggested we might establish contracts between schools and the college and offered an initial form of contract. Other schools agreed and a basic contract was drawn up and then signed in separate negotiation with each school.

At the beginning of our introductory phase we were successful in a second bid to explore the use of ICT in the learning and teaching of mathematics. We decided to incorporate this study into the LCM project, with extra focus on the use of software in some schools. Three of the 7 schools expressed an interest to be part of this wider project and one additional school joined specifically with an ICT focus. There are therefore now 8 project schools. 


\section{Developing as a team of didacticians and creating relationships with teachers}

Although the above account of bringing schools into the project may make the process seem straightforward, decisions on most of the actions described had to be discussed and agreed at some level by didacticians. At this stage we had an 8-person team, including 2 doctoral students recruited explicitly to the project (later, two more were appointed, making four in a ten-person team). Some members of the team were new to each other. Some had much greater knowledge and experience of local schools and relationships with teachers than others. Given that the proposal had been written and accepted without a contribution from schools, we now had to consider how to initiate and develop college-school relationships. The emergent negotiative process was one of community building for the didacticians, based within considerations of how to enable partnerships with schools to be developed. To enable community and partnership development, a team of three didacticians was linked to each school.

The initial meetings with schools had been designed to explain to teachers the theoretical perspectives on which our proposal was built and broad ways in which these might be achieved, and also to invite schools to question these perspectives and offer their own developmental goals. Inevitably, power at this stage lay with the didacticians who were promoting their own ideas and ideals, but from the beginning the schools offered a trenchant response, questioning the meaning of terms and the practicalities of what they saw to be proposed.

\section{Design and nature of workshops}

Our aims for workshops were twofold: to build community between didacticians and teachers, and to allow development of understandings about inquiry and its role in development. We decided to begin by working on mathematics together, through carefully designed problems and tasks. This should allow didacticians and teachers to develop a community based on understanding, respect and confidence, and lead to discussion about tasks for classrooms, ways of working in classrooms, and ways of achieving curriculum objectives ${ }^{3}$. A fundamental issue for didacticians was how to generate classroom activity through which pupils could achieve greater conceptual understanding of mathematics (our definition of 'better learning') than was currently the case.

From our planning meetings, the following pattern of workshop programme has emerged: introduction to the workshop; small group work on questions, tasks or problems (teachers and didacticians together); small group feedback; discussion of what we have learned; discussion of needs. Didacticians worked hard initially to decide the kinds of problems that would be useful. We considered, for example, whether to use curriculum-based problems or more open 'investigations'. We invited some teachers to an early planning meeting to get their perspectives on types of activity that teachers 
would welcome. We held six workshops in Phase 1 in which we hoped to achieve a progression from engaging together in mathematics to considering how inquiry in mathematics leads to mathematical learning, and further, to thinking about ways in which inquiry might take place in classrooms to address the curriculum at any level.

\section{Teacher planning, lesson design and classroom innovation}

An aim of the project was that the teacher team in each school would start to work on design of classroom activity with a goal of planning a set of lessons involving inquiry approaches which teachers would teach and of which we could explore the outcomes together. It was important to try to keep a record of developmental activity in schools, so data was sought from school planning meetings and other kinds of activity related to the project.

We planned that didacticians would visit schools periodically, join teachers in their discussion and provide support as jointly conceived. Three didacticians were linked with each school. In this planning we drew on theory and experience in other projects in which models for this kind of activity can be found, such as Japanese Lesson Study (e.g., Stigler \& Hiebert, 1999); Learning Study (Marton et al., 2003); and The Formative Assessment Project (Black, et al., 2002). Initial meetings with principals and teachers indicated that schools were keen for didacticians to visit and contribute to school development.

Whereas workshops designed and led by didacticians might be expected to follow to some degree what didacticians envisaged and planned, the parallel work in schools depended on visions and practices of schools and teachers, both in terms of the project and in the normal processes of school life. In the didactician team, we agreed to act in a responsive way to teachers, visiting schools, trying to discern how teachers interpreted the aims of the project for their school, and offering support accordingly. The project aims had been explained, set out in the contracts, and reinforced through the workshops. Teachers themselves had to be the ones to lead within the schools. Didacticians had to find ways of contributing to development in the schools.

According to the design of the project, an important part of practice in schools would be lessons in which teachers' design and planning were put into practice. We hoped to audio or video record such lessons wherever possible. It was envisaged that teachers would take some opportunity to observe each other, meeting at agreed intervals to reflect on the lessons and recognize issues, re-plan where necessary, and keep a record of thinking and outcomes. Didacticians would provide support as needed and whenever possible. They would also collect data in classrooms and conduct individual and focus group interviews with the teachers. 


\section{Data and Analysis}

It was planned that research would study practices in meetings, workshops and school activity through careful observation of events and that interviews would be conducted with teachers and didacticians during the project. Qualitative data would be sought to document all project activity and would include: notes (handwritten) from various activities; audio recordings (from planning meetings, interviews, workshops and lessons); video recordings (from workshops and lessons); and other data (from workshop tasks, problems, schedules; materials for use in classrooms). A first step in analyzing much of this data has been a data reduction process. This process involves writing a summary sheet that highlights the main topics and issues for each event from a mainly factual perspective. Summaries are then coded to aid a search of the data against specific research questions and allow finer grain analyses of relevant episodes.

The project proposal included a set of research questions relating to several broad areas of study. These questions were developed and refined during the early stages of Phase 1. Data and analysis have been conducted to address these questions, with much data addressing more than one question. Different researchers work singly or in teams on different questions. So far, data and its analysis is entirely within the domain of the didacticians.

\section{A case account from one school}

In this section, I offer a small-scale view of learning and development within the project to exemplify the main elements of project design and to start to indicate issues associated with the operationalization of this design. The school is an upper school (students aged 16-19). The school team has three teachers, and as with all the schools, there is a didactician team of three people associated with the school. Early in Phase 1, two didacticians visited the school and met with the three teachers to initiate and develop relationships and to explore the teachers' aims and expectations for the project in their school. The following table charts a sequence of activity together with the associated aims, implications and issues.

\begin{tabular}{|l|l|l|}
\hline $\begin{array}{l}\text { When \& } \\
\text { Where }\end{array}$ & What (action within the project) & Why (aims, implications and issues) \\
\hline $\begin{array}{l}\text { Early in } \\
\text { Phase 1 }\end{array}$ & $\begin{array}{l}\text { 2 didacticians visited the school and } \\
\text { met with the three teachers. } \\
\text { Teachers indicated that they had } \\
\text { School } \\
\text { meeting } \\
\text { on linear functions which they would } \\
\text { teach in the spring. }\end{array}$ & $\begin{array}{l}\text { To initiate and develop relationships. } \\
\text { To explore the teachers' aims and } \\
\text { expectations for the project in their } \\
\text { school. } \\
\text { Teachers' decisions and own focus } \\
\text { related to teaching of pupils and a }\end{array}$ \\
\hline
\end{tabular}




\begin{tabular}{|c|c|c|}
\hline & $\begin{array}{l}\text { Teachers drew didacticians into a } \\
\text { discussion of what the module would } \\
\text { involve, with particular reference to } \\
\text { their text book. } \\
\text { Ts and Ds discussed aspects of linear } \\
\text { functions, looking together at pages of } \\
\text { text and tasks in the text, talking about } \\
\text { key elements of linear functions that } \\
\text { teachers wanted to address, and } \\
\text { bringing in notions of inquiry related } \\
\text { to tasks \& textbook. } \\
\text { Teachers suggested that they would } \\
\text { like to hold a day workshop at the } \\
\text { college, with some didacticians } \\
\text { present, to take this work further. }\end{array}$ & $\begin{array}{l}\text { mathematical topic. Focus on the } \\
\text { mathematical topic and module of } \\
\text { work emphasizing importance of the } \\
\text { standard text book. } \\
\text { Collaborative activity between Ts and } \\
\text { Ds relating to teachers' agenda, } \\
\text { fulfilling didacticians' aims to develop } \\
\text { relationships and introducing ideas of } \\
\text { how inquiry can fit within 'normal' } \\
\text { learning and teaching activity. } \\
\text { Teachers' initiative to allow them to } \\
\text { get away from the pressures in school } \\
\text { to take their planning further and } \\
\text { collaborate further with didacticians. }\end{array}$ \\
\hline $\begin{array}{l}\text { Next mon } \\
\text { College } \\
\text { meeting }\end{array}$ & $\begin{array}{l}\text { Day workshop, organized by } \\
\text { didacticians, took place with } 2 \\
\text { teachers and } 2 \text { didacticians, and was } \\
\text { video recorded. }\end{array}$ & $\begin{array}{l}\text { Furthered planning of the teaching } \\
\text { module on linear functions. Further } \\
\text { development of understanding and } \\
\text { good will between Ts and Ds. } \\
\text { Data for analysis. }\end{array}$ \\
\hline & $\begin{array}{l}\text { Teachers designed tasks for students: a } \\
\text { set of four cards on which were } \\
\text { written questions for students to } \\
\text { tackle, with a progression of concepts } \\
\text { across the cards. }\end{array}$ & $\begin{array}{l}\text { The aim was that each of the three } \\
\text { teachers would use the cards with their } \\
\text { class of students, and didacticians } \\
\text { would video record the three lessons } \\
\text { for future analysis. }\end{array}$ \\
\hline $\begin{array}{l}\text { Next month. } \\
\text { School } \\
\text { teaching }\end{array}$ & $\begin{array}{l}\text { Three lessons took place; three } \\
\text { didacticians attended and video- } \\
\text { recorded the lessons. }\end{array}$ & $\begin{array}{l}\text { Realization of planning. Data for study } \\
\text { in relation to planning and perceptions } \\
\text { of all participants. }\end{array}$ \\
\hline $\begin{array}{l}\text { Colle } \\
\text { activ }\end{array}$ & $\begin{array}{l}\text { Didacticians selected episodes from } \\
\text { video material (6 episodes, two from } \\
\text { each class) for viewing with the } \\
\text { teachers: one episode of teacher } \\
\text { interaction with whole class and one } \\
\text { interaction with a small group, with } \\
\text { significant dialogue from students. }\end{array}$ & $\begin{array}{l}\text { Feedback to teachers from video } \\
\text { recording. Seeking teachers' } \\
\text { perspectives on the lessons as further } \\
\text { data to explore developmental aspects } \\
\text { of the activity so far. Gaining insights } \\
\text { into perceptions of inquiry and } \\
\text { community. }\end{array}$ \\
\hline & $\begin{array}{l}2 \text { didacticians and } 3 \text { teachers viewed } \\
\text { video episodes and discussed activity }\end{array}$ & $\begin{array}{l}\text { Congenial social setting to encoura } \\
\text { good relationships and trust in }\end{array}$ \\
\hline
\end{tabular}




\begin{tabular}{|c|c|c|}
\hline $\begin{array}{l}\text { didactician's } \\
\text { house }\end{array}$ & $\begin{array}{l}\text { and issues arising (details below). } \\
\text { Audio recorded. }\end{array}$ & $\begin{array}{l}\text { discussing issues. } \\
\text { Further data for analysis of community } \\
\text { building and developmental issues. }\end{array}$ \\
\hline $\begin{array}{l}\text { Next month. } \\
\text { Project } \\
\text { Workshop } \\
\text { at the } \\
\text { College }\end{array}$ & $\begin{array}{l}2 \text { teachers made an input, explaining } \\
\text { their planning process, describing } \\
\text { what happened in the classrooms, } \\
\text { showing one video episode and } \\
\text { presenting their reflections on the } \\
\text { whole activity. Subsequent small } \\
\text { group activity, in the workshop, } \\
\text { invited all participants to try out the } 4 \\
\text { tasks and reflect on ways such tasks } \\
\text { might be used at a range of levels to } \\
\text { foster students' learning. Video } \\
\text { recorded. }\end{array}$ & $\begin{array}{l}\text { Communication with other schools; } \\
\text { with teachers taking a lead. Providing } \\
\text { examples for other schools to consider. } \\
\text { Encouraging critical review of } \\
\text { designed activity and consideration of } \\
\text { its adaptation for other circumstances. } \\
\text { Giving a lead to other schools in the } \\
\text { design and implementation of tasks and } \\
\text { classroom activity. Data for further } \\
\text { analysis into community building and } \\
\text { awareness of inquiry processes. }\end{array}$ \\
\hline
\end{tabular}

Discussion in the video-viewing session with 3 teachers and 2 didacticians revealed a number of issues. For example, students' activity with the cards led to reconsideration of the language used. The original cards asked students to 'draw' a relationship between the coordinate pairs generated by a given algebraic rule $(x+y=7)$. Teachers had expected some sort of graph. Students had not known what to draw. Some had asked whether they should draw the numbers in some way. Teachers struggled with what alternative forms of wording might have enabled the students to understand their task more clearly. One teacher said he had been concerned about the amount of time given to the cards activity and its value relative to what it achieved. However, he reflected on what occurred in a subsequent lesson, suggesting that students gave evidence of having a clearer concept of the linear relationships than he might otherwise have expected. Teachers at this level have repeatedly expressed their worries about the time needed for inquiry-based work and the difficulties of giving such time within a demanding syllabus. Thus, here was one small indication that perhaps such time might be well spent (further details of this small study can be found in Hundeland, Erfjord, Grevholm and Breiteig, 2005).

One outcome of the reported activity was that another upper secondary school launched into action, planning classroom activity and inviting didacticians to video-record lessons. Teachers in the two schools contacted each other and arranged a meeting to discuss future activity within the project. These arrangements were reported to the school's didactician team and teachers requested a meeting between didacticians and teachers from the two schools. In this meeting, teachers were in strong voice about their 
reflections on the project and hopes for Phase 2. Some of what they expressed could be seen as critical of certain aspects of the project to date, and it was clear that such expression was an important step for the development of the project. Since then, didacticians and teachers have met to address similar issues and to plan for further workshops in Phase 2 of the project.

Our reporting above results from macro-analyses of the available data through the data reduction process and the beginning of finer-grain micro-analysis according to various research questions. The table shown above is also an analytical tool. As we complete related analyses, a fourth column will be added supporting (or otherwise) the claims made in column 3, indicating findings related to the events listed and thus linking development and research.

\section{Findings and Issues}

The case study reported above illustrates ways in which teachers and didacticians are working together for development in the project and suggests ways in which research is charting this development. While the design process created a framework of activity within which development would take place, the actual nature of the resulting activity and roles of the people involved could not be designed. The project proposal suggested that teachers would engage in their own design of classroom activity, but the project aimed to chart rather than to guide such a design process. The above case is especially interesting because it follows very closely what was originally envisaged. The teachers decided what they wanted to explore and sought support from didacticians. It was the teachers who led this process, choosing their mathematical focus, deciding they wanted

a day's meeting at the college, and subsequently designing the activity cards. In fact the teachers took the didactician team by surprise since the teachers asked us to film their lessons before our filming technology was in place. It galvanized us into action and we started our technical development of video production earlier than planned. However, this activity on the part of teachers is not typical and development was both slower and different in other schools.

Throughout our work so far, in a phase of community building, didacticians and teachers have started to work together and to negotiate activity according to each others' interests and goals. Respective roles have not been well defined. Outcomes so far can be seen in two major areas as discussed in the sections below.

\section{The developmental paradigm and roles of didacticians}

It seems important to start a discussion of findings and issues with a reminder that the project is both a development and a research project. The developmental paradigm in which we are working encourages a holistic approach in which research and development are two sides of the same coin in a reflexive relationship with each other. 
From the start didacticians have engaged in development and collected data from that engagement. It is, and has been, our intention to study engagement as well as the outcomes of it. One issue arising from such intentions concerns the roles of didacticians as developmental agents or researchers and possible overlap or conflict.

For example, consider a workshop setting in which participants work together in small groups on a mathematical problem. The aims of such activity are to develop community through engagement in mathematical inquiry, with a concomitant growth in understanding of the nature of inquiry and its contribution to learning mathematics. What role should didacticians play in interacting with teachers in such activity? Since teachers are largely unfamiliar with inquiry activity, didacticians have to provide some opportunity for engaging in inquiry and reflecting on inquiry processes. This could involve orchestrating activity in a group, suggesting questions that might be addressed, introducing explicitly metacognitive issues related to inquiry in learning and teaching, or sitting back so that teachers can take the lead and acting responsively. We asked ourselves how the role we played might influence the outcomes of activity and subsequent analysis of the recorded data. Discussion of such issues informed individual action in the workshops and in school meetings i.e. in developmental activity. Analysis of data from such discussions allows us to trace a developmental process in the contribution of didacticians to the project. From factual summaries of workshop planning meetings, we sought evidence of discussion. Scanning the summaries revealed two meetings in which there had been extensive discussion of didacticians' roles. These discussions were fully transcribed and micro-analyzed, line by line, to reveal the emergent understandings and issues related to roles. In Cestari et al. (2005), we provide evidence of the communicative and negotiative process of inspecting individual perspectives and agreeing terminology for ways we want to work; we trace the development of ideas through our dialogue; we start to see aspects of development of ideas as individuals adapt their perspectives within the community process; and we see a concomitant growth of community.

For example, in a discussion about a didactician's role in small groups within a workshop, various terms such as coordinator or facilitator were used. Differences emerged in how some didacticians saw these terms, indicating differing concepts of modes of interaction between didacticians and teachers. One person rejected the notion of being a coordinator as it implied being "the boss", for him an unacceptable role. One argument was that didacticians should not try to impose their own views or approaches, but rather facilitate teachers' activity and thinking. However, this was seen, possibly, to be in tension with a view that didactician input would be valuable in illustrating possibilities in problem-solving or in relating mathematical tasks to their potential for learning. So we ask how such input from didacticians might be realized in a process of development of partnership with teachers. This tension has proved to be important, 
though not resolved, and has stimulated a deep consideration of modes of interaction and their consequences with questions and indications for subsequent activity in the field.

Although all participants see time as a scarce resource, we have come to realize that the time taken for such (lengthy) discussions is invaluable for developing common understandings of the kinds of interaction and responses we should like to engage in, and for enabling individuals to make knowledgeable decisions in field situations. Analyses of data from subsequent interactions in workshops and schools will be related to analyses of early data from planning meetings. This process will allow us to relate planning with its implementation and allow us to examine what can be learnt from such juxtapositioning. In such analyses, the precise role played matters less than how that role related to subsequent activity, to growth of understanding of various sorts, and to the development of working knowledge about roles and associated activity (see, Goodchild and Jaworski, 2005, for an activity-theory-based analysis). We expect a significant contribution of this project to be its synthesis of such learning.

\section{Teachers' engagement in workshops and school groups}

Although didacticians' roles could be discussed in prospect and analysed in retrospect, teachers' roles have, until recently, only been analysed (by didacticians) in retrospect. Recently, in the move to Phase 2, development in teachers' roles has become more evident. However, I will talk about observation first from Phase 1.

All Phase 1 workshops included one or more sessions of mathematical activity in small groups. Didacticians thought long and hard about the mathematical problems or tasks that should form the basis of such activity. Problems varied from open-ended investigations to content-focused questions with some element of inquiry in them ${ }^{4}$. For example, at the suggestion of one of the schools, one workshop focused on probability. Where possible, most didacticians did not see the chosen problems in advance, so that teachers and didacticians could work together on 'new' problems. Enthusiasm and excitement, evident in teachers' reporting back from small group work, have indicated that the tasks both engaged and inspired teachers.

However, some teachers indicated that the level of mathematics has been too demanding. Others indicated that they would prefer to work with colleagues at their own level (rather than in cross-level groups), implying perhaps that the level of mathematics was not appropriate for them. Almost universally, teachers seemed to focus on the tasks themselves rather than the underlying inquiry processes and their implications for learning. This might of course reflect the familiar discourse, and perhaps that articulation of more abstract phenomena requires language that is as yet undeveloped within the project. Analysis here needs to try to tease out such aspects of language and an issue we are tracking is how or whether such facilitative language develops. 
Current analyses show that didacticians have not wanted to impose particular forms of activity on teachers, rather wanting schools to define their own approaches to the project. Schools have looked for certain kinds of contribution from didacticians and have not always been satisfied with the kinds of response perceived. So, for example, in designing workshop activity, didacticians have tried to provide opportunities for seeing inquiry processes through the particular problems and tasks. However, they have seen it as important that teachers decide themselves how to work on the tasks and how to follow up in schools. Recent feedback from teachers has suggested that more specific involvement from didacticians in school activity would be valuable, such as spending time in classrooms and talking with teachers about developing the teaching that has taken place.

Another tension for teachers concerns the place of inquiry within their practice. We have observed differences across the schools according to the age of pupils taught. Some teachers in the lower and middle schools seem more relaxed about using new tasks and trying out inquiry approaches with pupils. It has been suggested that it is easier at this level to find time for innovation, since there is no pressure from tests or examinations. Some teachers in the upper secondary schools seem primarily focused on the mathematics they have to teach and the demands of the curriculum and tests, leaving little space for inquiry activity. At all levels, some teachers see inquiry as involving tasks that are 'extra' to 'normal' school and classroom activity. Normal activity in schools, importantly for teachers, depends on the time available for different classroom approaches. Fitting in project activity can be seen to consume more time than teachers are willing to give. A challenge, therefore, is for us all to develop understandings of how inquiry approaches can become part of 'normal' activity.

It has been a challenge to deal with the growing realization of what it means for teachers and didacticians genuinely to work together and deal with these tensions in designing activity that is inquiry-based. It is not so much a question of how didacticians draw teachers into didacticians' ways of being and thinking, as of trying to enter into teachers' own concerns and work with them to develop inquiry-based activity in ways that makes sense according to teachers' and schools' aims for development. What are the most fruitful ways of working with teachers to enable clearer understandings of creating activity that is fruitful for pupils' learning of mathematics? As we (didacticians) address such challenges, we must look critically at our own aims and perspectives and try to see things from teachers' and schools' points of view. Data and analysis do allow us to address didacticians' developmental issues. A harder task is getting the data that allows us to examine teachers' and schools' points of view.

Towards the end of Phase 1, teachers were starting to become more vocal as to how they would like to go ahead with the project, and more decisive about the kinds of activity they want to pursue in schools. Recent meetings have started to open up a discussion on 
teachers' expectations of the project and ways in which they want didacticians to contribute to school development. Two thirds of the teachers in the project attended a planning meeting for Phase 2 workshops and many were vociferous in the style of workshops they would like. An outcome of this discussion is that workshops will allow teachers to start planning jointly for classroom activity while in the workshop. It seems that there is a move towards a clearer expression of voice on the part of the teachers, and a question we are asking currently is how this will relate to the inquiry basis of the project, a possible further source of tension.

\section{The ongoing nature of development and research}

It is interesting that the Norwegian language has no direct translation for the word "inquiry". It has been explained in terms of other words that can be translated, but the word itself has entered the Norwegian discourse in our project. Teachers talk, in Norwegian, about 'inquiry', and its place in their work. We have data that suggests a growing perception of what inquiry can mean, although this is still, often, in the mode of special activity, beyond the norm, whether for pupils in the classroom or in terms of teachers' planning of lessons. In Wenger's terms, as expressed earlier, teachers are engaged in a community of practice of teaching in their school within the school system in Norway. They are aligned with the norms of their practice, such as familiar organization and lesson planning, use of textbooks and so on. They exercise imagination in planning for pupils' activity within these norms. Within the project we are seeking to develop inquiry ways of thinking and being. For this purpose, Phase 1 has proved to be a conceptualization phase as well as one of community building. Inquiry ways of thinking and being have started to take shape through activity in our workshops and through meetings between teachers and didacticians in schools related to design of classroom activity. We are seeing this new thinking already offering challenges to existing norms. Teachers have to continue to work within their familiar practice. Although, within the project, they are committed to exploring notions of inquiry, they challenge ideas about inquiry and ask how it is possible to engage in inquiry without taking extra time beyond normal ways of working. Didacticians see a need to shift the focus of this challenge towards the status quo, the established norms of current practice. This shift would involve a form of critical alignment for teachers: questioning the demands of existing norms of practice and starting to formulate new possibilities, albeit maintaining equilibrium in terms of workload and commitments to pupils. We hope that some teachers will take on research tasks related to development of their own teaching. Such re-alignment requires forms of meta-thinking and awareness which are slow to develop and enter into practice. We continue to work towards such goals, charting the developmental processes as we go.

\section{Notes}


${ }^{1}$ The LCM Project is supported within the KUL Programme (Kunskap, Utdanning og Laering - Knowledge, Education and Learning) of the Norwegian Research Council (Norges Forskningsraad, NFR). Project number 157949/S20.

${ }^{2}$ The term didacticians means those professionals with responsibility for theorising teaching. We avoid the term 'educator' since it is ambiguous - teachers are also educators - although didacticians may also be teacher-educators; i.e., professionals with responsibility for teacher education.

${ }^{3}$ The Norwegian National Curriculum was redeveloped in 1997 and the mathematics part includes a strong focus on investigative tasks leading to conceptual understanding.

${ }^{4}$ An example of each: 1) Eight people stand on a 3x3 square grid with a corner position vacant. If people can only move to an empty adjacent square, how many moves will it take for the person in the diagonally opposite corner to move to the free space? Generalise. 2) A farmer sends his 50 sheep to mountain pasture in the summer. It is estimated that the risk of not getting a sheep back again is 0.05 . What is the probability that he gets back all of his sheep? What is the probability that $1 / 2 / 3$... are missing? How many sheep is it most probable that he gets back?

\section{References}

Alseth, B. Breiteig, T, Brekke, G. (2003). Endring og utvikling ved R97 som bakgrunn for videre planlegging og justering. Rapport Norges Forskningsråd.

Black, P., Harrison, C., Lee, C., Marshall, B and Wiliam, D. (2002). Working inside the black box: Assessment for learning in the classroom. London: Kings College, Department of Education and Professional Studies.

Brekke, G. (1995). Kartlegging av matematikkforståelse: Introduksjon til diagnostisk undervsining i matematikk. Oslo; Nasjonalt læremiddelsenter.

Cestari, M-L., Daland, E., Eriksen, S. \& Jaworski, B. (2005). Working in a developmental research paradigm: the role of didactician/researcher working with teachers to promote inquiry practices in developing mathematics learning and teaching. Paper accepted for the CERME4 conference, Spain, February 2005.

Chaiklin, S. (1993). Understanding the Social Scientific Practice of Understanding Practice. In Chaiklin, S. \& Lave, J. (Eds.) Understanding Practice: Perspectives on Activity and Context. Cambridge: Cambridge University Press.

Cobb, P. (1996). Where is the mind? A Coordination of Sociocultural and Cognitive Constructivist Perspectives. In C. Twomey Fosnot (Ed.), Constructivism: Theory, Perspectives, and Practice, pp 34-52. NY: Teachers College Press.

Elliott, J. (1991). Action Research for Educational Change. Milton Keynes: Open University Press.

Glasersfeld, E. von (1995) Radical Constructivism. London: Falmer Press. 
Goodchild, S. \& Jaworski, B. (2005). Identifying contradictions in a teaching and learning development project. In H. L. Chick \& J. L. Vincent, (Eds.), Proceedings of the $29^{\text {th }}$ Conference of the International Group for the Psychology of Mathematics Education, pp 41-47. Melbourne, Australia: University of Melbourne.

Hundeland, P. S., Erfjord, I., Grevholm, B., \& Breiteig, T. (2002) Teachers and Researchers Inquiring into Mathematics Teaching and Learning: The Case of Linear Functions. Paper presented at the NORMA 05 Conference (Nordic Research in Mathematics Education), Trondheim, September, 2005

Jaworski, B (1994). Investigating Mathematics Teaching.. London: Falmer Press. Jaworski, B. (2003). Research Practice into/influencing Mathematics Teaching and Learning Development: Towards a Theoretical framework based on co-learning partnerships. Educational Studies in Mathematics. 54, 2-3, 249-282.

Jaworski, B. (2004a). Grappling With Complexity: Co-Learning In Inquiry Communities In Mathematics Teaching Development. In M. J. Høines \& A. B. Fuglestad (Eds.), Proceedings of the $28^{\text {th }}$ Conference of the International Group for the Psychology of Mathematics Education, pp 17-32. Bergen, Norway: Bergen University College.

Jaworski, B. (2004b). Insiders and Outsiders in Mathematics Teaching Development: the design and study of classroom activity. In O. Macnamara and R. Barwell (Eds.), Research in Mathematics Education: Papers of the British Society for Research into Learning Mathematics, pp 3-22. London: BSRLM.

Jaworski B. (in press) Theory and Practice in Mathematics Teaching Development: critical inquiry as a mode of learning in teaching. Journal of Mathematics Teacher Education, 9.2. Special Issue: Relations between Theory and Practice in Mathematics Teacher Education.

Kelly, A. E. (2003). Research as Design. Educational Researcher, 32, 1, 3-4

Lave, J. (1993). In Chaiklin, S. \& Lave, J. (Eds.) Understanding Practice: Perspectives on Activity and Context. Cambridge: Cambridge University Press.

Lave, J. \& Wenger, E. (1991.) Situated Learning: Legitimate Peripheral Participation. Cambridge, MA: Cambridge University Press.

Marton, F., Tsui, A. B. M., Chik, P. P. M., Ko, P. Y., Lo, L. M., Mok, I. A. C., Ng, D. F. P., Pang, M. F., Pong, W. Y., and Runesson, U. (2003). Classroom Discourse and the Space of Learning. Mahwah, N. J.: Lawrence Erlbaum.

Mason, J., Burton, L., \& Stacey, K. (1982). Thinking Mathematically. London: AddisonWesley.

Mason, J. (2001). Researching your own Classroom Practice: From Noticing to Reflection. London: Routledge Falmer.

McIntyre, D. (1997). The Profession of Educational Research. British Educational Research Journal, Vol 23 no. 2, pp. 127-140.

Polya, G. (1945). How to Solve It. Princeton NJ: Princeton University Press

Schoenfeld, A. H. (1985). Mathematical Problem Solving. New York: Academic Press. 
Skoland Andreassen, Irene (2005). Innsikt i elevers kompetenser som vises i skriftlige matematikktester. Masteropgave i matematikkdidaktikk. Kristiansand: Høgskolen i Agder. Stigler, J., \& Hiebert, J. (1999). The Teaching Gap. New York: The Free Press. Vygotsky, L. (1978). Mind in Society. Cambridge: Harvard University Press.

Wagner, J (1997). The Unavoidable Intervention of Educational Research: A Framework for Reconsidering Research-Practitioner Cooperation. Educational Researcher, 26, 7, 1322.

Wells, G. (1999). Dialogic Inquiry: Toward a Sociocultural Practice and Theory of Education. Cambridge: Cambridge University Press.

Wenger, E. (1998). Communities of Practice: Learning, Meaning and Identity. Cambridge: Cambridge University Press.

Wittmann, E. C. (1998). Mathematics Education as a 'Design Science'. In A. Sierpinska and J. Kilpatrick (Eds.), Mathematics Education as a Research Domain: A Search for Identity. (87-103) The Netherlands: Kluwer Academic Publishers. 